\title{
Decrease in two intestinal copper/zinc containing proteins with antioxidant function in inflammatory bowel disease
}

\author{
T P J Mulder, H W Verspaget, A R Janssens, P A F de Bruin, A S Peña, C B H W Lamers
}

\begin{abstract}
Oxygen derived radicals contribute to tissue injury in inflammatory bowel disease. We measured the content of superoxide dismutase and metallothionein (two endogenous copper and zinc containing proteins involved in radical scavenging) in intestinal resection specimens from 29 patients with Crohn's disease and 12 patients with ulcerative colitis and compared the concentrations with those obtained in the normal mucosa of a control group of 18 patients with colorectal cancer. The superoxide dismutase content was similar in control mucosa and non-inflamed mucosa from patients with inflammatory bowel disease (mean (SEM) 2.13 (0.10) and $2 \cdot 24(0 \cdot 10) \mathrm{mg} / \mathrm{g}$ protein, respectively) but was decreased in inflamed mucosa $(1.87(0.08) \mathrm{mg} / \mathrm{g}$ protein, $\mathrm{p}<0.005 v$ non-inflamed mucosa). The metallothionein content was decreased in noninflamed inflammatory bowel disease mucosa compared with control mucosa $(0.23(0.03)$ and $0.36(0.04) \mathrm{mg} / \mathrm{g}$ protein, respectively, $\mathrm{p}<0.02)$ and a further decrease was found in inflamed mucosa $(0.17(0.02) \mathrm{mg} / \mathrm{g}$ protein, $\mathrm{p}<0.001 v$ control mucosa). No differences were found between Crohn's disease and ulcerative colitis and no significant effect of medication or tissue localisation was noted. These findings might indicate a decreased endogenous intestinal protection against oxygen derived radicals in inflammatory bowel disease which could contribute to the pathogenesis of the disease.
\end{abstract}

A growing body of data indicates that oxygen derived free radicals such as superoxide $\left(\mathrm{O}_{2}^{-}\right)$, hydrogen peroxide $\left(\mathrm{H}_{2} \mathrm{O}_{2}\right)$, and hydroxyl radicals $\left(\mathrm{OH}^{*}\right)$ have a role in mediating intestinal damage in inflammatory bowel disease. The intestine is well endowed with enzymes capable of producing such free radicals.' Moreover, when inflammation is present the many phagocytic cells that are attracted and activated can produce large amounts of free radicals. Several studies suggest that peripheral blood monocytes ${ }^{2}$ and isolated intestinal macrophages ${ }^{34}$ from patients with inflammatory bowel disease produce increased amounts of free radicals. Also high numbers of peripheral neutrophils, which are capable of producing large amounts of oxygen derived free radicals, ${ }^{5}$ migrate into the intestinal wall of such patients. ${ }^{6}$

Grisham and Granger ${ }^{7}$ hypothesised that in ulcerative colitis transient ischaemic episodes and subsequent reperfusion produce high levels of free radicals. This process initiates a cascade leading to the recruitment and activation of leucocytes, resulting ultimately in mucosal ulceration. Recently, Wakefield et $a l^{8}$ presented evidence for multifocal infarctions in the intestine of patients with Crohn's disease, indicating that ischaemic episodes may also occur in this disease.

Several studies indicate that sulphasalazine and its active metabolite 5-aminosalicylic acid are efficient scavengers of oxygen radicals in vitro. ${ }^{9-11}$ These scavenging potentials may be an important mode of action of these drugs in vivo. $^{72}$ Data, however, on endogenous antioxidant proteins in the intestinal mucosa of patients with inflammatory bowel disease are lacking. For that reason we measured two copper and zinc containing proteins with radical scavenging potential in the intestinal mucosa of patients with inflammatory bowel disease, metallothionein and superoxide dismutase.

Metallothionein is an ubiquitous metal binding protein whose main function is the regulation of copper and zinc metabolism. ${ }^{13}$ Thornalley and Vašák $^{14}$ were the first to note the high $\mathrm{OH}^{\text {' }}$ scavenging potentials of metallothionein. Since then it has been found to protect DNA molecules, cells in culture, and whole organisms against the detrimental effects of several types of free radical generating treatments. ${ }^{15-17}$

Copper/zinc containing superoxide dismutase is a cytoplasmic enzyme that catalyses the dismutation of $\mathrm{O}_{2}^{-}$to $\mathrm{H}_{2} \mathrm{O}_{2}$. The enzyme protects the organism against the toxic reactions of $\mathrm{O}_{2}^{-}$and also against the transition metal catalysed HaberWeiss reaction $\left(\mathrm{O}_{2}^{-}+\mathrm{H}_{2} \mathrm{O}_{2} \stackrel{\mathrm{Fe}, \mathrm{Cu}}{>}>\mathrm{O}_{2}+\mathrm{OH}^{-}\right.$ $\left.+\mathrm{OH}^{\bullet}\right)$, which generates the very reactive $\mathrm{OH}^{*}$ radical. Bovine superoxide dismutase preparations have been used in preliminary clinical trials with patients with various inflammatory disorders and dramatic improvement has been reported in four of four patients with Crohn's disease and three of four patients with ulcerative colitis. ${ }^{18}$ Emerit et al ${ }^{19}$ reported a beneficial effect in $82 \%$ of patients with Crohn's disease with longterm treatment, with bovine superoxide dismutase.

The objectives of the present study were to determine the concentrations of these two copper and zinc containing antioxidant proteins in the intestinal mucosa of patients with Crohn's disease and ulcerative colitis and to compare these with the values obtained in control mucosa.

\section{Methods}

PATIENTS

Twenty nine patients with Crohn's disease and 12 patients with ulcerative colitis who were 
operated on were included in the study. The diagnosis was based on routine clinical, endoscopic, and radiological criteria and confirmed by histological evaluation of the resected part of the intestine. The Crohn's disease patients consisted of 14 females and 15 males, median age 34 years (range 14-79). The ulcerative colitis patients were six females and six males, median age 35 years (range 23-68). At the time of operation six and two patients respectively were taking sulphasalazine or 5-aminosalicylic acid, five and two were taking corticosteroids, and five and two were taking both 5-aminosalicylic acid or sulphasalazine and corticosteroids. The corticosteroid dose ranged from 5-50 mg/day and the dose of the other two drugs from $0 \cdot 5-6$ g/day. The other 19 patients had no medical treatment. Indications for surgery were failure of medical treatment to control a clinical relapse or intestinal obstruction.

Histologically normal tissue specimens from 18 patients, 12 males and six females, median age 72 years (range 53-85) who underwent surgery for colorectal cancer, were included as controls.

\section{TISSUE SPECIMENS}

A total of 19 specimens of ileum and 16 of large bowel from the 29 Crohn's disease patients were available. From these specimens a total of 65 samples were analysed. From the 12 patients with ulcerative colitis we obtained 12 specimens from the large bowel and one from the ileum, and 21 tissue samples were analysed. Representative parts of macroscopically normal and inflamed tissue were selected by the pathologist and confirmed histologically by analysis of adjacent tissue. From the colorectal cancer patients histologically normal colon specimens were taken at least $10 \mathrm{~cm}$ from the neoplastic lesion. The mucosa was dissected from the tissue specimens and frozen at $-70^{\circ} \mathrm{C}$ until further use.

The extraction procedure was as follows. The specimens were thawed and 50-100 mg samples were prepared. The samples were wet weighed and $1 \mathrm{ml}$ of $0.1 \mathrm{~mol} / 1$ Tris- $\mathrm{HCl} \mathrm{pH} 7.5$ with $0 \cdot 1 \%(\mathrm{v} / \mathrm{v})$ Tween 80 per $60 \mathrm{mg}$ was added. The tissue was homogenised for two minutes in an ice bath using a teflon pestle. The homogenates were centrifuged twice for three minutes at $8000 \times g$ at $4^{\circ} \mathrm{C}$ and the final supernatants were stored at $-70^{\circ} \mathrm{C}$. Protein concentrations in all homogenates were determined using the method of Lowry et $a l^{20}$ with bovine serum albumin as standard.

\section{METALLOTHIONEIN DETERMINATION}

The metallothionein concentration in the homogenates was measured using a recently developed radioimmunoassay. ${ }^{21}$ Metallothionein was isolated from the liver of a patient with primary biliary cirrhosis by a combination of Sephadex G-75 gel permeation and DEAE Sephadex A-25 anion exchange chromatography. The purity of the preparation was confirmed by gel electrophoresis. ${ }^{22}$ An antiserum against metallothionein was raised in rabbits. Metallothionein was labelled with iodine- 125 using the method of Bolton and Hunter. ${ }^{23}$ The radioimmunoassay buffer consisted of $0.05 \mathrm{~mol} / \mathrm{l}$ Tris- $\mathrm{HCl} \mathrm{pH} 8 \cdot 0,0 \cdot 1 \%$ (w/v) gelatine and $0.01 \%(w / v) \mathrm{NaN}_{3}$. Incubations contained $0.5 \mathrm{ml}$ standard or sample, $0.1 \mathrm{ml}$ rabbit anti-metallothionein serum in a $1 / 10000$ final dilution and $0 \cdot 1 \mathrm{ml}{ }^{125} \mathrm{I}$-metallothionein diluted to give about 4000 counts per minute. The standard line ranged from $1-100 \mathrm{ng}$ metallothionein $/ \mathrm{ml}$ and mucosa samples were diluted 1/400, 1/800, and 1/1600. After incubation for four days at $4^{\circ} \mathrm{C}$ the antibody bound fraction was precipitated by incubation with $0.5 \mathrm{ml}$ of a suspension containing microsepharose beads coupled to sheep antirabbit antibodies. The radioactivity of the pellets obtained after centrifugation was counted. Intraassay and interassay coefficients of variation were both determined by five duplicate measurements of five different intestinal mucosa samples and calculated as standard deviation $/$ mean $\times 100 \%$. The mean intra-assay and interassay coefficients of variations were $3 \%$ and $7 \%$, respectively.

\section{SUPEROXIDE DISMUTASE DETERMINATION}

The copper/zinc superoxide dismutase was determined by an enzyme linked immunosorbent assay (ELISA) as described previously. ${ }^{5}$ It was purified from erythrocytes as described by McCord and Fridovich..$^{2+}$ Antibodies were raised in goats and affinity purified by chromatography with superoxide dismutase coupled to $\mathrm{CNBr}$ activated Sepharose 6B. The double antibody sandwich ELISA was performed as follows. Antibodies were coated $(10 \mathrm{mg} / \mathrm{ml}$ in carbonate buffer $\mathrm{pH} 9.6$ ) overnight at $4^{\circ} \mathrm{C}$ to polyvinylchloride ELISA plates. After washing the plates were incubated with $2 \%$ pre-immune goat serum at room temperature for two hours. After a second wash standards of purified superoxide dismutase $(1-50 \mathrm{ng} / \mathrm{ml})$ or intestinal mucosa homogenates (diluted $1 / 800,1 / 1600$, and $1 / 3200$ ) were added $(0.1 \mathrm{ml}$ in phosphate buffered saline, $0 \cdot 1 \%(\mathrm{w} / \mathrm{v})$ Tween 20$)$ and incubated at room temperature for two hours. After a third wash antibody to superoxide dismutase coupled with peroxidase was added (1/12500 dilution) and incubated for one hour at room temperature. After a final wash the plates were coloured with an orthophenylenediamine $-\mathrm{H}_{2} \mathrm{O}_{2}$ solution for 30 minutes. The reaction was stopped with $2 \cdot 5$ $\mathrm{mol} / 1 \mathrm{H}_{2} \mathrm{SO}_{4}$ and the colour read spectrophotometrically at $492 \mathrm{~nm}$. The mean intra-assay and interassay coefficients of variation were $4 \%$ and $6 \%$, respectively.

\section{STATISTICAL ANALYSIS}

All data were calculated as mg superoxide dismutase or mg metallothionein per $g$ total protein and expressed as mean (SEM). To compare the groups Student's $t$ test was used, or when standard deviations were significantly different the separate variance analysis. Differences were considered significant below $\mathrm{p}=0 \cdot 05$.

\section{Results}

The amounts of superoxide dismutase and metallothionein in the intestinal mucosa of inflammatory bowel disease patients are shown 


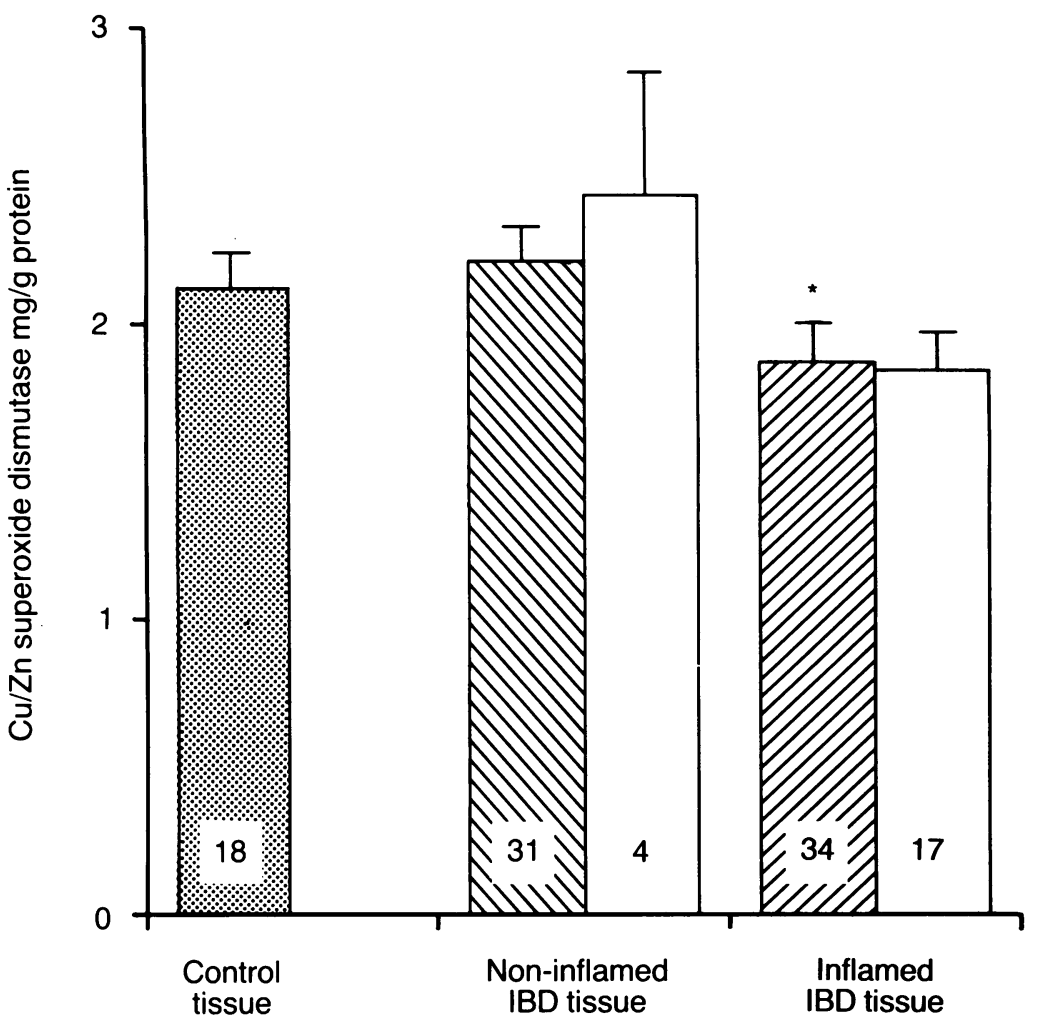

Figure 1: Copper/zinc containing superoxide dismutase concentrations in the intestinal mucosa samples from patients with Crohn's disease (hatched bars), patients with ulcerative colitis (open bars), and control subjects. ${ }^{\star} p<0.05$ significance of difference $\mathrm{v}$ non-inflamed.

in Table I. Non-inflamed mucosa from the patients contained a concentration of superoxide dismutase similar to that in control mucosa and a significant decrease in the concentration was found in inflamed mucosa $(\mathrm{p}<0.005 v$ non-

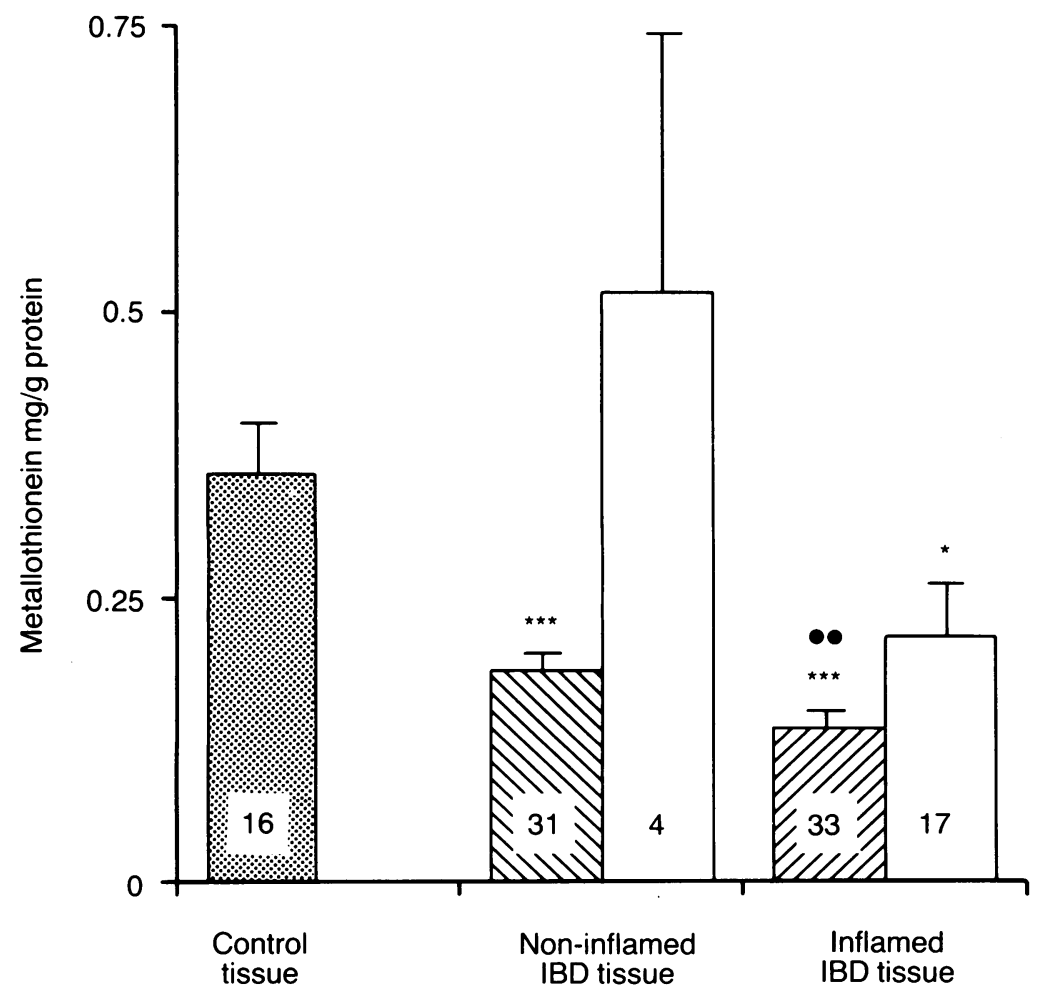

Figure 2: Metallothionein concentration in the intestinal mucosa samples of patients with Crohn's disease (hatched bars), patients with ulcerative colitis (open bars), and control subjects. ${ }^{\star} p<0.05, \star \star \star p<0.001$ significance of difference $\mathrm{v}$ controls. $\bullet \bullet p<0.01$ significance of difference $\mathrm{v}$ non-inflamed.
TABLE I Copper/zinc superoxide dismutase and metallothionein concentrations in intestinal mucosa samples from patients with inflammatory bowel disease and control subjects. (Mean (SEM)) ( $n=$ number of samples)

\begin{tabular}{lll}
\hline & $\begin{array}{l}\text { Superoxide dismutase } \\
(m g / g \text { protein })\end{array}$ & $\begin{array}{l}\text { Metallothionein } \\
(m g / g \text { protein })\end{array}$ \\
\hline $\begin{array}{l}\text { Control subjects } \\
\begin{array}{l}\text { Inflammatory bowel } \\
\text { disease: }\end{array}\end{array}$ & $2 \cdot 13(0 \cdot 10)(\mathrm{n}=18)$ & $0.36(0.04)(\mathrm{n}=16)$ \\
$\begin{array}{l}\text { Non-inflamed } \\
\text { Inflamed }\end{array}$ & $\begin{array}{l}2 \cdot 24(0 \cdot 10)(\mathrm{n}=35) \\
1 \cdot 87(0.08) \ddagger(\mathrm{n}=51)\end{array}$ & $\begin{array}{l}0 \cdot 23(0.03) \star(n=35) \\
0.17(0.02) \dagger(\mathrm{n}=50)\end{array}$ \\
\hline
\end{tabular}

${ }^{\star} \mathrm{p}<0.02,+\mathrm{p}<0.001$ significance of difference $v$ controls; $\ddagger \mathrm{p}<0.005$ significance of difference $v$ non-inflamed.

inflamed). The superoxide dismutase concentrations in ulcerative colitis and Crohn's disease mucosa were almost identical (Fig 1).

Although ileal mucosa seemed to contain more superoxide dismutase than colon mucosa, the concentrations in ileal and colon mucosa did not differ significantly when inflamed and noninflamed tissue were considered (Table II). Moreover, despite the fact that more than half of the patients (22/41) were taking 5-aminosalicylic acid, sulphasalazine, or corticosteroids, or a combination, no significant effect of medication on the superoxide dismutase content of the intestinal mucosa was found (Table II).

The non-inflamed intestinal mucosa from the patients contained significantly less metallothionein than control mucosa $(p<0 \cdot 02)$. A further decrease in the concentration was found in inflamed mucosa (Table I) and in Crohn's disease the inflamed mucosa contained significantly less metallothionein than non-inflamed tissue ( $<<0.01$, Fig 2). The metallothionein concentration was higher in ulcerative colitis mucosa than in Crohn's disease mucosa in both non-inflamed and inflamed samples, but the difference was not significant (Fig 2). The high mean concentration in non-inflamed ulcerative colitis mucosa was caused by one extremely high value $(1.14 \mathrm{mg} / \mathrm{g}$ protein) from a patient on no medication.

Colon mucosa seemed to contain more metallothionein than ileal mucosa, although when inflamed and non-inflamed mucosa were considered the difference was not significant (Table II). Medical treatment also had no significant influence on the metallothionein concentration in the intestinal mucosa (Table II).

\section{Discussion}

In this study we report decreased concentrations of two copper/zinc containing antioxidant proteins in the inflamed intestinal mucosa of inflammatory bowel disease patients. The concentration of superoxide dismutase in patients' non-inflamed mucosa was similar to that in control mucosa but the concentration was decreased in inflamed mucosa. The metallothionein concentration in patients' non-inflamed mucosa was significantly lower than that in control tissue and a further decrease was found in inflamed samples. No major differences were found between ulcerative colitis and Crohn's disease, and neither tissue localisation - ileum or colon - nor medication was found to be respons- 
TABLE II Copper/zinc superoxide dismutase and metallothionein concentrations in intestinal mucosa samples from patients with inflammatory bowel disease in relation to tissue origin and medical treatment. (Mean (SEM)) ( $n=$ number of samples)

\begin{tabular}{|c|c|c|c|c|}
\hline & \multicolumn{2}{|c|}{ Superoxide dismutase (mg/g protein) } & \multicolumn{2}{|c|}{ Metallothionein ( $\mathrm{mg} / \mathrm{g}$ protein) } \\
\hline & Non-inflamed & Inflamed & Non-inflamed & Inflamed \\
\hline $\begin{array}{l}\text { Ileum } \\
\text { Colon } \\
\mathrm{p}\end{array}$ & $\begin{array}{l}2 \cdot 37(0 \cdot 12)(n=19) \\
2 \cdot 09(0 \cdot 15)(n=16) \\
0 \cdot 14\end{array}$ & $\begin{array}{l}2.03(0 \cdot 16)(n=20) \\
1 \cdot 77(0.08)(n=31) \\
0.14\end{array}$ & $\begin{array}{l}0 \cdot 18(0 \cdot 01)(n=19) \\
0 \cdot 29(0 \cdot 06)(n=16) \\
0 \cdot 12\end{array}$ & $\begin{array}{l}0.15(0.02)(n=19) \\
0 \cdot 18(0.03)(n=31) \\
0.47\end{array}$ \\
\hline $\begin{array}{l}\text { No medication } \\
\text { On medication } \\
\text { p }\end{array}$ & $\begin{array}{l}2 \cdot 20(0 \cdot 12)(n=19) \\
2 \cdot 29(0 \cdot 16)(n=16) \\
0.62\end{array}$ & $\begin{array}{l}1.92(0.11)(n=29) \\
1.80(0.11)(n=22) \\
0.47\end{array}$ & $\begin{array}{l}0.25(0.05)(n=19) \\
0.20(0.03)(n=16) \\
0.34\end{array}$ & $\begin{array}{l}0 \cdot 19(0 \cdot 03)(\mathrm{n}=29) \\
0 \cdot 14(0 \cdot 01)(\mathrm{n}=21) \\
0 \cdot 10\end{array}$ \\
\hline
\end{tabular}

ible for the observed changes in superoxide dismutase and metallothionein.

Parks et $a l^{25}$ developed a feline intestinal ischaemia/reperfusion model to study oxygen radical mediated damage. Grisham et al ${ }^{26}$ reported a $30 \%$ decrease in superoxide dismutase activity in this model though no decrease in catalase activity was found. They suggest that this indicates a selective inactivation of superoxide dismutase. Our non-inflamed mucosa samples from patients with inflammatory bowel disease contained superoxide dismutase concentrations similar to those in control mucosa but the concentration was decreased in inflamed samples, showing a direct relation between inflammation and superoxide dismutase concentration. Thus impairment of superoxide dismutase in inflamed mucosa might be caused by inactivation through high local concentrations of free radicals ${ }^{2627}$ and by a reduced local concentration of the enzyme. In the past we have reported a decreased superoxide dismutase concentration in peripheral blood granulocytes from inflammatory bowel disease patients with active disease, ${ }^{5}$ indicating that decreased cellular superoxide dismutase concentrations may be a more general inflammation related phenomenon in this disease, the mechanism of which is not yet known. The relevance of superoxide dismutase mediated tissue protection against injury related to reactive oxygen metabolites has recently been shown in an experimental colitis model where the inflammation was appreciably reduced by treatment with superoxide dismutase. ${ }^{28}$ Moreover, preliminary data suggest that superoxide dismutase also has beneficial effects in inflammatory bowel disease patients. ${ }^{18} 19$

When $\mathrm{O}_{2}^{-}$and $\mathrm{H}_{2} \mathrm{O}_{2}$ are not scavenged efficiently they can react in an iron or copper catalysed Haber-Weiss reaction and form the very reactive $\mathrm{OH}^{-}$radicals. The scavenging of $\mathrm{OH}^{*}$ radicals had beneficial effects in ischaemia/ reperfusion models for inflammatory bowel disease, ${ }^{17}$ and 5 -aminosalicylic acid was reported to be a potent scavenger of $\mathrm{OH}^{*}$ radicals in vitro. ${ }^{929}$ Since metallothionein is a sacrificial target protein for these radicals the decrease we found in inflamed intestinal mucosa might be attributed to high local concentrations of free radicals.

Elmes et al ${ }^{30}$ demonstrated metallothionein in the human ileum using an immunohistochemical technique. They reported intracellular staining of enterocytes and cells in the lamina propria and some extracellular staining near the basement membrane. Ileal biopsy specimens from patients with Crohn's disease showed reduced staining compared with control specimens. The reduced metallothionein score in Crohn's disease they reported agrees with the reduction in metallothionein concentration we found.

In contrast to the superoxide dismutase concentration the metallothionein concentration in non-inflamed inflammatory bowel disease mucosa was less than that in control mucosa, and a further decrease was found in inflamed samples. The synthesis of metallothionein is regulated in cell-type specific tissue by several factors including tissue zinc concentrations and several hormones. ${ }^{31}$ Crohn's disease patients have been reported frequently to have zinc deficiency ${ }^{32}$ which might contribute to the low intestinal metallothionein concentrations found in non-inflamed mucosa samples. Other indirect mechanisms are also possible. Solomons et al ${ }^{33}$ found that the reduced circulating zinc concentrations in Crohn's disease patients with acute inflammation were highly correlated with raised interleukin-1 activity. Moreover Cousins and Leinart $^{34}$ reported decreased intestinal and serum zinc concentrations and increased liver metallothionein synthesis in rats injected with human interleukin-1.

We detected no significant effect of medication on the intestinal mucosa superoxide dismutase or metallothionein concentrations, although the latter concentration was lower in patients on medication. In rats high doses of dexamethasone have been used as a potent inducer of metallothionein synthesis, but recent data suggest that at more physiological conditions glucocorticoids are slightly inhibitory. ${ }^{35}$ Elmes $e t a l^{30}$ reported a further reduction in immunohistochemical staining for metallothionein in the intestinal mucosa of Crohn's disease patients taking corticosteroids compared with patients taking no such drugs, whose mucosa already showed reduced staining compared with that from control subjects, but clinical assessment of the patients is lacking.

The decrease in superoxide dismutase and metallothionein in the intestinal mucosa with inflammation might contribute to a decrease in intestinal protection against oxidative damage which may be relevant to the tissue damage in inflammatory bowel disease. Treatments aimed at increasing the mucosal concentrations of copper/zinc containing antioxidant proteins might be a useful addition to the usual 5aminosalicylic acid or corticosteroids treatment in inflammatory bowel disease.

This study was supported by a grant (NLD 85-10) from The Netherlands Digestive Diseases Foundation. We are grateful to W van Duijn for expert technical assistance and to $M$ Koster-de Vreeze, N Koek-van Beelen, and L Niepoth for typing the manuscript.

Parks DA. Oxygen radicals: mediators of gastrointestinal pathophysiology. Gut 1989; 30: 293-8.

2 Kitahora T, Suzuki K, Asakura H, Yoshida T, Suematsu M, Watanabe $M$, et al. Active oxygen species generated by monocytes and polymorphonuclear cells in Crohn's disease. Dig Dis Sci 1988; 33: 951-5.

3 Verspaget $\mathbf{H}$, Beeken W. Mononuclear phagocytes in the gastrointestinal tract. Acta Chir Scand 1985; 25 (suppl): 11326.

4 Mahida YR, Wu KC, Jewell DP. Respiratory burst activity of intestinal macrophages in normal and inflammatory bowel disease. Gut 1989; 30: 1362-70.

5 Verspaget HW, Peña AS, Weterman IT, Lamers CBHW Diminished neutrophil function in Crohn's disease and 
ulcerative colitis identified by decreased oxidative metabolism and low superoxide dismutase content. Gut 1988; 29: 223-8

6 Crama-Bohbouth GE, Arndt JW, Peña AS, Verspaget HW, Tion A Tham RTO, et al. Value of indium-111 granulocyte scintigraphy in the assessment of Crohn's disease of the small intestine: prospective investigation. Digestion 1988;40: 227-36.

7 Grisham MB, Granger DN. Neutrophil-mediated mucosa injury. Role of reactive oxygen metabolites. Dig Dis Sci 1988; 33: 6-15S

8 Wakefield AJ, Sawyerr AM, Dhillon AP, Pittilo RM, Rowles PM, Lewis AAM, et al. Pathogenesis of Crohn's disease: multifocal gastrointestinal infarction. Lancet 1989; ii: $1057-$ 62 .

9 Aruoma OI, Wasil M, Halliwell B, Hoey BM, Butler J. The scavenging of oxidants by sulphasalazine and its metabolites. Biochem Pharmacol 1987; 21: 3739-42

10 Miyachi Y, Yoshioka A, Imamura S, Niwa Y. Effect of sulphasalazine and its metabolites on the generation of reactive oxygen species. Gut 1987; 28: 190-5.

11 Suematsu M, Susuki M, Miura S, Nagata H, Oshio C, Asakura $\mathrm{H}$, et al. Sulfasalazine and its metabolites attenutate res$\mathrm{H}$, et al. Sulfasalazine and its metabolites attenutate res-
piratory burst of leukocytes - a possible mechanism of antipiratory burst of leukocytes - a possible mechanism of an

12 Dull BJ, Salata K, Van Langenhove A, Goldman P. 5 Aminosalicylate: oxidation by activated leukocytes and protection of cultured cells from oxidative damage. Biochem Pharmacol 1987; 36: 2467-72.

13 Bremner I. Involvement of metallothionein in the hepatic metabolism of copper. 7 Nutr 1987; 117: 19-29.

14 Thornalley PJ, Vašák M. Possible role for metallothionein in protection against radiation-induced oxidative stress. Kinetics and mechanism of its reaction with superoxide hydroxyl radicals. Biochim Biophys Acta 1985; 827: 36-44.

15 Abel J de Ruiter N. Inhibition of hydroxyl-radical-generated DNA degradation by metallothionein. Toxicol Lett 1989; 47: $191-6$

16 Bakka A, Johnsen AS, Endresen L, Rugstad HE. Radioresistance in cells with high content of metallothionein. Experientia 1982; 38: 381-3.

17 Matsubara J. Alteration of radiosensitivity in metallothionein induced mice and a possible role of $\mathrm{Zn}$-Cu-thionein in GSHperoxidase system. Experientia 1987; 52 (suppl): 603-13.

18 Niwa Y, Somiya K, Michelson AM, Puget K. Effect of liposomal-encapsulated superoxide dismutase on active oxygen-related human disorders. A preliminary study. Free Radic Res Commun 1985; 1: 137-53.

19 Emerit J, Pelletier S, Tosoni-Verlignue D, Mollet M. Phase II trial of copper zinc superoxide dismutase (CuZnSOD) in treatment of Crohn's disease. Free Radic Biol Med 1989; 7 $145-9$.

20 Lowry OH, Rosebrough NJ, Farr AL, Randall RJ. Protein measurement with the folin phenol reagent. $7 \mathrm{Biol} C$ Chem 1951; 193: 265-75.

21 Mulder TPJ, Janssens AR, Verspaget HW, Lamers CBHW. Development of a radioimmunoassay for human metalloDevelopment of a radioimmunoassay for hum

22 Mulder TPJ Janssens AR, Verspaget HW, Lamers CHBW Isolation, characterization and determination of human live Isolation, characterization and determination of human liver

23 Bolton AE, Hunter WM. The labelling of proteins to high specific radio-activities by conjugation to a ${ }^{125}$ I-containin acylating agent. Biochem $\tilde{f}$ 1973; 133: 529-39.

24 McCord JM, Fridovich I. Superoxide dismutase. Enzymatic function for erythrocuprein (hemocuprein). $\mathcal{F}$ Biol Chem 1969; 244: 6049-55

25 Parks DA, Bulkley GB, Granger DN, Hamilton SR, McCord $J M$. Ischemic injury in the cat small intestine: role of superoxide radicals. Gastroenterology 1982; 82: 9-15.

26 Grisham MB, Hernandez LA, Granger DN. Xanthine oxidase and neutrophil infiltration in intestinal ischemia. $\mathrm{Am}$ Physiol 1986; 251: G567-74.

27 Jewett SL, Cushing S, Gillespie F, Smith D, Sparks S Reaction of bovine-liver copper-zinc superoxide dismutase with hydrogen peroxide. Eur f Biochem 1989; 180: 569-75.

28 Keshavarzian A, Morgan G, Sedghi S, Gordon JH, Doria M. Role of reactive oxygen metabolites in experimental colitis. Gut 1990; 31: 786-90.

29 Del Soldato P, Campieri M, Brignola C, Bazzocchi G Gionchetti P, Lanfranchi GA, et al. A possible mechanism of action of sulfasalazine and 5-aminosalicylic acid in inflammatory bowel diseases: interaction with oxygen free radicals. Gastroenterology 1985; 89: 1215-6.

30 Elmes ME, Clarkson JP, Jasani B. The immunocytochemica demonstration of metallothionein in human liver and small demonstration of metallothionein in human liver and smal
intestine. Acta Pharmacol Toxicol 1986;59 (suppl): 510-3.

31 Dunn MA, Blalock TL, Cousins RJ. Metallothionein. Proc Soc Exp Biol Med 1987; 185: 107-19.

32 Hendricks KM, Walker WA. Zinc deficiency in inflammatory bowel disease. Nutr Rev 1988; 46: 401-8

33 Solomons NW, Elson CO, Pekarek RS, Jacob RA, Sandstead HH, Rosenberg IH. Leukocytic endogenous mediator in Crohn's disease. Infect Immun 1978; 22: 637-9.

34 Cousins RJ, Leinart AS. Tissue-specific regulation of zinc metabolism and metallothionein genes by interleukin FASEB 7 1988; 2: 2884-90.

35 Hidalgo J, Giralt M, Garvey JS, Armario A. Physiological role of glucocorticoids on rat serum and liver metallothionein in of glucocorticoids on rat serum and liver metallothionein in
basal and stress conditions. Am $\mathcal{F}$ Physiol 1988; 254: E71-8. 